\title{
Corporate Governance, Risk Management and Ethical Investment: Evidence From Banking Industries
}

\author{
Amzad Hossain ${ }^{1}$, Farid A. Sobhani ${ }^{1}$, Normah Omar $^{2}$, Norazida Mohamad ${ }^{2}$ \& Jamaliah Said $^{2}$ \\ ${ }^{1}$ Department of Business Administration, International Islamic University Chittagong, Bangladesh \\ ${ }^{2}$ Accounting Research Institute, Universiti Teknologi Mara, Malaysia \\ Correspondence: Farid A. Sobhani, Department of Business Administration, International Islamic University \\ Chittagong, Bangladesh.
}

Received: April 30, 2019

Accepted: May 30, 2019

Online Published: June 10, 2019

doi:10.5430/ijfr.v10n5p126

URL: https://doi.org/10.5430/ijfr.v10n5p126

\begin{abstract}
Considering the importance of good corporate governance in the banking industry, the study has been designed to investigate the managerial perceptions on interrelationship among good corporate governance, risk management, and ethical investment of the commercial banks of Bangladesh. Bangladesh has been selected as a field of study for three reasons. Firstly, banking is the leading sector in Bangladesh. Secondly, banking sector has been highly criticized in the recent times due to Bangladesh Bank scandal. Thirdly, banking is gradually being challenging services in Bangladesh. As a financial intermediary, bank has to ensure good corporate governance for smooth operations and reducing agency problem. As a trustee, bank deals with the money of others through various schemes of investment. Ethical investment known as social responsible investment is an indicator of good corporate governance. A structured questionnaire has been used to gather perceptions of managers of the sample banks. The results suggest that the most important factors for effective CG were the board of directors, auditors and managers of the various departments. The study also finds that risk taking behavior of the bank is influenced by the direction of board of directors. In this study corporate governance variables have been categorized with some sub-indices. Board's structure with independent directors and well communication with supervisors ensure the efficient risk management practices in the banks where internal audit system and transparent disclosures of the board ensure the ethical investment practices.
\end{abstract}

Keywords: perception, bankers, corporate governance, risk management, ethical investment, Bangladesh

\section{Introduction}

Bank plays an intermediary role of contract (Macey and O'hara, 2003; Ge, et.al 2018) in financial market. It arranges a variety contracts among the clients to choose which they prefer. By having corporation nature banks have to comply with rules and regulations to ensure smooth operations. In every country, central bank imposes certain rules and regulations under which all schedule banks operate. Beyond these rules and regulations, banks need to follow a complete governance system because banks operate for their stakeholder as a trustee. People invest their money in various deposit schemes having a trust that the bank will not default in contract. By mobilizing these deposited funds, banks invest the funds to the various sectors. Here stakeholders believe that banks' investment behavior will not be unethical. Hence, ethical investment is a vital issue in view of business ethics for banking operations.

Ethical investment is known as social responsible investment that brings welfare for investors and society. The main driving strategy is that the investors will not invest the funds in the sectors that will be harmful or illegal. Investors want that banks should follow proper corporate governance in managing the investment portfolio which is ethical. Ethical investment is not a new term. Every religious order is concerning ethics and morality for the followers. Responsible investors want to invest ethically that is an emerging demand of ethical investment schemes nowadays. Again this driving force is not a new demand. Basically establishment of Islamic bank was due to meet the need of ethical investment. When Middle East countries had surplus fund the European and Asian countries were experiencing a growth in Islamic finance (Brown and Skully, 2006). Investors invest in ethical investment by considering both company structure and risk-return As stated by EIRIS (1999), average return of ethical investment has greater than conventional fund having comparative low risk (EIRIS 1999). Investor feels encouraged if the 
institutions invest their funds in ethical sectors and ignore the risk and uncertainties (Renneboog et al., 2006; Islam, Muhammad Adnan Hye \& Shahbaz 2012).

Banks face risk from several sources like operational, market, liquidity etc. Risk hinders the proper growth of the banks and ultimately affects the performance of banks. Stockholders want to avoid risk and appoint agent to perform on behalf of stockholder as per agency theory. Agent is also known as board of directors who are appointed to perform organizational activities and delivered appropriate information to the stakeholders. When agent does not meet the expectation of the stakeholder there might be created an agency problem. Good corporate governance is necessary to reduce the agency problem that ensures the interest of the stakeholders. Investment strategy is one of the major elements of risk management (Santomero, 1997). If banks actively manage the investment procedures, credit and liquidity risk may be reduced. Ethical investment offers reasonable return than conventional one (Hussein, 2004). Again good corporate governance offers an efficient risk management of the bank (Nworji et al., 2011; Gérard \& Oumbé 2018). It is obvious that there is a strong relationship among corporate governance, risk and ethical investment.

A good number of studies are available on corporate governance, risk and ethical investment. But no study so far has been conducted concerning managerial perceptions on those issues. Bangladesh has been selected as a field of study as the issues of corporate governance, risk and ethical investment are being raised time to time from different corners. Few corporate scandals like Hallmark and Sonali Bank's scams in Bangladesh in the recent times demand in depth study in those fields. Hence, this paper is designed to know the perception of selected practicing bankers regarding corporate governance, ethical investment and risk in the banking sector of Bangladesh.

Both Islamic and conventional banks have been selected for this study. Appointments are sought from the senior bankers like Managing Director, Chief Executive Officer, Chief Finance Officer, Chief Risk Officer, Corporate Secretary and managers of banks' branches of the leading banks. A questionnaire with five point Likert Scale is designed to gather perceptions on corporate governance, risk and ethical investment followed by factors behind their understanding, status of those issues in their individual banks and the like. The interview results are presented in descriptive style stating their individual words under quoted marks as be recorded during interview. The interview findings are critically analyzed based on the Institutional and System Theories.

\section{Literature Review}

This section highlights the prior studies related with corporate governance and risk management in financial institutions. Most of the studies like Tsorhe et al. (2011), Calomiris \& Carlson (2016), Aebi et al. (2012), Willesson (2015), Pirson \& Turnbull (2011), Faleye \& Krishnan (2010), Greuning \& Bratanovic (2003) focused on the relationship of corporate governance and risk management of the bank.

\subsection{Corporate Governance and Risk Management}

Banks play as an interest intermediary. Interested stakeholders are concerned about their funds which is invested and also how the banks manage the risk exposures faced by the banks. Bank's risks may be systematic and unsystematic which are affected by the internal and external factors. Banks performed within the guidelines of the central bank regulation where central bank guides the banks in the interest of the stakeholders. Controlling and monitoring the operations of banks to serve the public interest, regulators impose corporate governance guidelines which control the managerial behavior of banks.

Tandelilin et al. (2007) analysed ownership struture of banks with corporate governance, risk management and bank performance by the primary and secondary data. In their study they found that the relationship between corporate governance and risk management is sensitive to bank ownership struture. A study was conducted by Faleye \& Krishnan (2010) on the effect of bank performance on risk-taking in commercial lending and found that in lending to borrowers the banks are less risky which have effective boards. Tsorhe et al. (2011) investigated about the impact corporate governance on some major risks: capital risk, credit risk and liquidity risk in the Ghanaian banking industry. By using regression analysis where board indices was used as a proxy of the board of directors in corporate governance they found that banking regulation has negative impact on all three major risks of their study where no statistical difference was found between the means and medians of strong boards vis-à-vis weak board.

The prsence of chief risk officer (CRO) in bank's executive board was investigated by Aebi et al., (2012) to find out the relationship whether the risk management is affected by the corporate governance. They found that the banks whose the CRO reports directly to the board had better performance in financial crisis. To be better performance in risk management, banks should implement risk governance having CEO and CRO. Willesson (2015) found the 
relationship to risk with board size and board independence. The study also concluded that banking risk is only affected by the board independence.

\subsection{Corporate Governance and Ethical Investment}

Good governance in the firm ensures the ethical assurance of the firm's investment (Louche, 2004). Ethical investment was originated from $18^{\text {th }}$ century in U.S. and captured by the investors who avoid the investment of enterprises that engaged violence activities. By the inspiration from the success of ethical investment, in Europe a good numbers of financial institutions engaged in ethical investment by introducing ethical fund. A few numbers of studies like Hussein (2004), Anas \& Mounira (2009), Richardson (2009), Louche (2004), Bansal \& Roth (2000), Schäfer (2004), Brown \& Skully (2006), Ghanney, (2018) are related to the performance of and regulatory issues ethical investment.

Tippet (2001) analyzed the performance of Australia's ethical fund over 1992 to 1998 by using Jensen ratios. Results suggested that there are two basically issues about ethical investment: the nature of the company's product or service, and the behavior of company management. Second issue concern about such matters as directors' remuneration and independence of auditors. A study on socially responsible investment and corporate environmental reporting was conducted by Friedman \& Miles (2001). The study revealed that social movement, corporate behavior, shareholder activism, screening criteria, collectivism, constructive dialogue and ethical considerations which are core of corporate governance are significant factors influencing ethical investment.

The investment decision process of ethical investment was analyzed by Hofmann et al. (2007). They used questionnaire whereas data from 286 participants were collected. They suggested that ethical investment decision is mostly influenced by the moral intensity which led the moral judgment to invest ethically. It seems that there are many challenges in the field of ethical investment. One of the major challenges is the understanding the complexity of investment practices and corporate behavior. Development of mechanism which focuses the ethical behavior of companies attracts the actual and potential investors and also social screening influence in the investment decision (Ahmed, Khalid, Ammar \& Shah, 2017; Michelson et al., 2004; Goral \& Akgoz 2017; Junaid, 2018).

The above studies indicate that there are many studies in the field corporate governance, risk management and ethical investment. However, no study is found available in these fields concerning the perceptions of the senior bankers in Bangladesh. Hence, the study has contributory effect in the field of scholarship and knowledge body of literature.

\section{Methodology}

In this study two sets of questionnaire have been used to assemble primary data regarding corporate governance, risk management and ethical investment. Variables taken for corporate governance have been used for assessing perceptions on risk management and ethical investment of the bank. To judge in detail between corporate governance and risk management we have also sub-divided the variables into some sub-indices.

\subsection{Variable Selection}

In the economy bank plays a vital role by intermediating between savers and borrowers that help to drive economic growth. Bank's smooth running in its functions ensures financial stability and key to determine economic health. Basel committee sets thirteen principles in corporate governance of bank. Based on these principles in our study we have used twelve variables of corporate governance with sub indices cited in previous studies (Akram et al., 2014, Amba 2014, Haldar 2012, Beasely 1996, Black et. al. 2006, Yeamack 1996, Adams et. al.2003, Durnev \& Kim 2005; Kaine, Iku \& Ebigwai 2015) to judge relationship of corporate governance with risk management and ethical investment.

Variable 1: Board's overall responsibilities

The overall responsibilities of board for the bank are approving and implementing of the bank's strategic objectives, governance framework, corporate culture and risk appetite. Sub indices of this variable are: responsibilities of the board, corporate culture and values, duty with loyalty of the board's members and key personnel selection by the board.

Variable 2: Board qualifications and composition

Board members should be well qualified to understand the corporate governance role and be able to exercise sound judgment about the fairs of the bank. Sub indices of this variable are: board composition and board member selection and qualifications. 
Variable 3: Board's own structure and practices

Board has the ultimate duty to define appropriate governance structures and practices for daily works within the banks and also to follow the ongoing effectiveness through various committees. Sub indices of this variable are: role of the chair, audit committee, risk committee, compensation committee, human resources committee, ethics and compliance committee.

Variable 4: Senior management

As directed by the board, the senior management carries out and manages the daily activities of the banks in accordance with policies set by the board. Sub indices of this variable are: accountability to board and transparency in procedures and decision-making.

Variable 5: Independent risk management

Independent risk management under the supervision of Chief Risk Officer (CRO) is needed to manage all risks in banks. The CRO periodically revises the ongoing process of all risks involved in banking activities and provides information to the board to take remedial measure. Sub indices of this variable are: role of CRO and early warning or trigger system of the bank's risk appetite.

Variable 6: Internal control infrastructure of bank's risk management

Bank's internal control infrastructure of risk management should be kept pace with bank's risk profile and external environment so that operational and market risk of the bank can be easily measured and controlled. Sub indices of this variable are: internal and external data about the risk exposures, risk identification should be linked with off-balance sheet items, quantitative analysis should be done rather than qualitative analysis, stress test of the employees and updated technical instruments.

Variable 7: Communication System

Robust communication within the bank about risk ensures the sound governance. Strong risk culture promotes risk taking behaviour across the bank and also encourages open communication with board about the strategy for risk management. Sub indices of this variable are: timely information sharing system, discussion with business unit by the senior management and assumption layering information.

Variable 8: Compliance System

Board of directors is responsible for managing the bank's compliance risk. Board has the ultimate responsibility in policies making of compliance functions in accordance with risk profile of the bank. Sub indices of this variable are: compliance in top management and accountability of board in compliance function.

Variable 9: Internal audit System

Internal audit system ensures the effective governance process in all aspects. Clear and transparent reporting system of internal audit ensures accountability of the board and all employees in the banking functions. Sub indices of this variable are: independent and qualified internal audit function, skilled staffs in audit committee and percentage of outside auditors in audit committee.

Variable 10: Compensation System

Compensation structure of bank should be compensation structure should be associated with risk management which influences the risk taking behaviour. Sub indices of this variable are: incentive structure, compensation of senior executives and performance based compensation.

Variable 11: Disclosure and transparency

Governance of the bank should be transparent to its stakeholders, shareholders, depositors and market participants. Proper disclosure of bank's information influences the bank's performance in risk management because it reduces asymmetric information in the market. Transparency of employee to senior management and board handles the operational risk of the bank. Sub indices of this variable are: key points disclosure of risk in annual report, timely disclosure and transparency board's members in annual general meeting (Suryanto, Haseeb, \& Hartani, 2018).

Variable 12: The role of supervisors

Supervisors should evaluate on performance of every units like risk management and give remedial measures where necessary. Supervisors should also interact with the board in corporate governance and suggest in improvement of the bank efficiency. Sub indices of this variable are: evaluation of strategic issues in risk management, evaluation of selection process of board's members and regular interaction with board and senior management. 


\subsection{Data Collection}

The study is based on primary data, which were collected through structured questionnaire. Personnel interviews were taken with $\mathrm{CEO}$, senior management, managing director, chief finance officer, chief risk officer, corporate secretary and the banks' managers of different branches.

\subsubsection{Sample Selection}

At present there are fifty six (56) scheduled banks operating in Bangladesh. Among them, six (6) are state-owned commercial banks (SOCBs), two (2) specialized banks, thirty nine (39) private commercial banks, and nine (9) foreign commercial banks (FCBs). There are total 4,895 branches of the scheduled banks operating across the country. For the survey 356 respondents were determined as sample size by using sample size formula.

\subsubsection{Statistical Analysis}

Data were examined using the Statistical Package for the Social Sciences Software (SPSS) to determine frequencies, means and standard deviations. To identify the major issues of corporate governance, risk management ethical investment we used factor analysis. To asses factorability of the data for factor analysis we measured Kaiser-Meyer-Olkin value of the variables (Results shown in appendix).

\section{Analysis and Findings}

A total of 417 respondents gave their opinion on 5 point Likert Scale, we have employed Varimax Rotated Factor Analytical techniques to identify the major variables of corporate governance that effect in risk management and ethical investment of the bank. In this study variables have been categorized as most significant, significant and insignificant on the basis of mean score of opinions taken from 5 point Likert scale. Finally we have also ranked the sub indices of variables on the basis of their magnitudes.

Table 1. Variables of corporate governance that effect on risk management of bank based on mean Weighted Scores

\begin{tabular}{|c|c|c|}
\hline Variable ID & Weighted Mean Score & Std. Deviation \\
\hline \multicolumn{3}{|c|}{ Most Significant } \\
\hline $\mathrm{V}_{12}$ & 3.76 & 1.02 \\
\hline $\mathrm{V}_{9}$ & 3.70 & 1.01 \\
\hline $\mathrm{V}_{10}$ & 3.56 & 1.13 \\
\hline \multicolumn{3}{|l|}{ Significant } \\
\hline $\mathrm{V}_{2}$ & 3.46 & 1.16 \\
\hline $\mathrm{V}_{11}$ & 3.38 & 1.11 \\
\hline $\mathrm{V}_{7}$ & 3.30 & 1.20 \\
\hline $\mathrm{V}_{5}$ & 3.24 & 1.23 \\
\hline $\mathrm{V}_{4}$ & 3.18 & 1.09 \\
\hline $\mathrm{V}_{1}$ & 3.08 & 1.23 \\
\hline $\mathrm{V}_{6}$ & 3.07 & 1.19 \\
\hline $\mathrm{V}_{8}$ & 3.03 & 1.26 \\
\hline \multicolumn{3}{|l|}{ Insignificant } \\
\hline $\mathrm{V}_{3}$ & 2.72 & 1.24 \\
\hline
\end{tabular}

Above Table 1 has been constructed based on the weighted mean score of each variable. From the above table it has been seen that role of supervisors in board $\left(\mathrm{V}_{12}\right)$, internal audit system $\left(\mathrm{V}_{9}\right)$ and compensation system $\left(\mathrm{V}_{10}\right)$ are most significant where board qualifications and composition $\left(\mathrm{V}_{2}\right)$, disclosure and transparency $\left(\mathrm{V}_{11}\right)$, communication system $\left(\mathrm{V}_{7}\right)$, independent risk management $\left(\mathrm{V}_{5}\right)$, senior management $\left(\mathrm{V}_{4}\right)$, board's overall responsibilities $\left(\mathrm{V}_{1}\right)$, internal control infrastructure of bank's risk management $\left(\mathrm{V}_{6}\right)$, compliance system $\left(\mathrm{V}_{8}\right)$ are significant and finally board's own structure and practices $\left(\mathrm{V}_{3}\right)$ is insignificant. 


\subsection{Principal Component Analysis of Corporate Governance in Bank's Risk Management}

To reduce variables in this study, principal component analysis technique has been used and found three factors of the variables. Total variance accounted for by all three factors is $49.13 \%$ and the remaining variance is explained by other factors.

Table 2. Factor analysis

\begin{tabular}{lll}
\hline Variable ID & Variables & Factor Loading \\
\hline $\mathrm{V}_{7}$ & Communication system & 0.759 \\
\hline $\mathrm{V}_{6}$ & Internal control infrastructure of bank's risk management & 0.715 \\
\hline $\mathrm{V}_{1}$ & Board's overall responsibility & 0.689 \\
\hline $\mathrm{V}_{4}$ & Senior management & 0.570 \\
\hline $\mathrm{V}_{3}$ & Board's own structure and practices & 0.550 \\
\hline $\mathrm{V}_{10}$ & Compensation system & 0.541 \\
\hline $\mathrm{V}_{5}$ & Independent risk management & 0.539 \\
\hline $\mathrm{V}_{8}$ & Compliance system & 0.436 \\
\hline & Variance accounted for & $26.210 \%$
\end{tabular}

This factor contains 1 most significant variable, 6 significant variables and 1 insignificant variable. This factor explains $26.210 \%$ of the total variations existing in the variable set.

\subsection{Communication System}

This variable has highest factor loading than other variables. After analyzing its sub indices it has been found that timely information sharing to board reduces the operational risk (Mean score $=2.47$ ). If the employees of the bank share their ongoing activities update to the board then the board can easily evaluate the performance and take remedial measures where any mistake found which ensures the efficiency of works and may reduce the operational risk. Operational risk arises from the operational activities of the bank. If the employees of the bank strongly manage the investment activities then the operational risk may be reduced. Ethical investment may need time to time updated information to avoid operational risk by which the risk management can be more efficient. Assumption layering information about risk helps the board to take proper strategy in risk management (Mean score $=2.45$ ). Assumption layering information may also help the board to understand the consequence of risk exposures in banking system. Ethical investment needs assumption layering information before investment because before doing investment banks should justify the legitimacy of investment. Regular discussion by the board's members with every business units helps the board to ensure the efficiency of risk management (Mean score $=1.58$ ).

\subsection{Internal Control Infrastructure of Bank's Risk Management}

Stress testing of employees in their working environment reduces the operational risk of the bank (Mean score $=2.90)$ and also their techniques used in measuring risk exposures ensures the efficient risk management (Mean score $=$ 2.82). Board periodically will review the stress test report and also the performance of the techniques used in risk management. Bank should consider the internal and external data in assessing market risk (Mean score $=2.39$ ) with quantitative analysis rather than qualitative analysis (Mean score $=2.40$ ). Board should assess the off-balance sheet items in reducing operational risk exposures (Mean score $=1.55$ ).

\subsection{Board's Overall Responsibility}

In the selection of key personnel like Chief Executive Officer, Chief Risk Officer etc. board's members should be transparent (Mean score $=2.74$ ) and perform their duties with loyalty (Mean score $=2.69$ ). Bank should also select the key personal who will understand the purposes of ethical investment. If they don't know the ethical investment process then they can't ensure the ethics in investment. The board has the ultimate responsibility to adopt strategy in risk management (Mean score $=2.29$ ) which ensures corporate culture and values. Integrated corporate culture and values adopted by the board positively influence the efficiency of the market risk management of the bank (Mean score $=1.65$ ). 


\subsection{Senior Management}

Senior management of the bank is responsible implementing the strategy of the board in risk management with much more accuracy and should be accountable to board to be efficient in risk management (Mean score $=2.38$ ). Accountability and transparency throughout decision making for the risk management by the senior management may reduce the operational risk of the bank (Mean score $=1.67$ ).

\subsection{Board's Own Structure and Practices}

Though this variable is insignificant in risk management but its sub indices have influential effect in risk management. Ethics and compliance committee ensures the proper ethical standard in risk management and promotes in decision making by implementing compliance policy (Mean score $=2.70$ ). Human resource committee provides recommendation in selecting the key personnel in risk management to run the risk management function efficiently (Mean score $=2.69$ ) and works with risk committee to develop the individual in assessing risk exposures (Mean score $=2.38$ ). Compensation committee is required to support the board in supervision the remuneration system's for the long-term and risk appetite (Mean score $=1.70$ ).

\subsection{Compensation System}

Compensation of senior executives like CEO, CRO, Head of different units approved by the board ensures the proper functioning of risk management (Mean score $=2.90$ ). Performance based compensation system of the employees increases the efficiency of employees in managing risk and also motivates them to work in accordance with risk management policies (Mean score $=2.20$ ) which also ensures the efficiency of risk management of the bank (Mean score $=2.16$ ).

\subsection{Independent Risk Management}

The Chief Risk Officer (CRO) is the head of the risk management department performs the strategic objectives stated by the board in managing risk of the banks with risk officers. The efficient role of the CRO positively influences the efficient risk management o the bank's risk management (Mean score $=2.36$ ). The risk management body should be independent and separated from revenue oriented activities and its early warning about the issues related to risk ensures the smooth functioning of the bank (Mean score $=1.55$ ).

\subsection{Compliance System}

Compliance system has an influential role in the corporate values, processes and policies of the bank. Independent functioning and accountability of board in compliance functions are crucial in reducing risk management (Mean score $=2.89$ ). Compliance system in top management motivates lower management to run smooth functions in risk management process (Mean score $=2.24$ ).

Table 3. Factor analysis

\begin{tabular}{lll}
\hline Variable ID & Variables & Factor Loading \\
\hline $\mathrm{V}_{12}$ & Role of supervisors in board & 0.748 \\
\hline $\mathrm{V}_{11}$ & Disclosure and transparency & 0.730 \\
\hline & Variance accounted for & $11.58 \%$ \\
\hline
\end{tabular}

This factor contains 1 most significant variable and 1 significant variable. This factor explains $11.577 \%$ of the total variations existing in the variable set.

\subsection{Role of Supervisors in Board}

Though board and senior management is responsible for implementing governance in the bank but their activities are evaluated by the supervisors. Evaluation of strategic issues in risk management by the supervisors may reduce the risk of the bank (Mean score $=2.94$ ). Such evaluations may be carried out through interviews with board's members and employees. As part of their evaluation of the overall corporate governance in a bank, supervisors should also evaluate the selection process of board's members to ensure the effectiveness of strategy taking in risk management (Mean score $=2.30$ ). Supervisors should interact regularly with boards, senior management and respective personnel in risk management to ensure the proper functioning of risk management (Mean score $=2.21$ ). 


\subsection{Disclosure and Transparency}

Transparency in works and detailed disclosures of bank ensure proper governance across the bank. In annual general meeting of the bank board should be much more transparent to its shareholders and disclose the risk position of the bank (Mean score $=2.95$ ). Board should disclose bank's overall risk position in annual report (Mean score $=2.87$ ) and the disclosure should be in timely basis (Mean score $=2.19$ ).

Table 4. Factor analysis

\begin{tabular}{lll}
\hline Variable ID & Variables & Factor Loading \\
\hline $\mathrm{V}_{9}$ & Internal audit system & 0.733 \\
\hline $\mathrm{V}_{2}$ & Board qualifications and composition & 0.713 \\
\hline & Variance accounted for & $11.376 \%$ \\
\hline
\end{tabular}

This factor also contains 1 most significant variable and 1 significant variable. This factor explains $11.577 \%$ of the total variations existing in the variable set.

\subsection{Internal Audit System}

Internal audit system provides independent assurance to the board effectiveness of a bank's internal control, risk management and governance thereby helping the board and senior management protect their bank (Mean score $=$ 3.71). Audit committee staffs should be accountable to the board and sufficient knowledgeable, skilled and well qualified to assess the risks across the banking operation (Mean score $=3.28$ ). Percentage of outside auditors in audit committee helps the bank to assess the material risk of the bank (Mean score $=2.88$ ).

\subsection{Board Qualifications and Composition}

Board should have a sufficient number of independent directors to carry out its responsibilities and should be comprised of individuals with a balance of skills, diversity and expertise, who collectively possess the necessary qualifications accordance with the size, complexity and risk profile of the bank (Mean score $=2.33$ ). Members selection in board should be clear and meticulous process for ensuring proper planning for risk management (Mean score $=1.68)$.

Table 5. Principal component analysis of corporate governance in bank's ethical investment

\begin{tabular}{|c|c|c|}
\hline Variable ID & Weighted Mean Score & Standard Deviation \\
\hline \multicolumn{3}{|c|}{ Most significant } \\
\hline $\mathrm{V}_{9}$ & 4.03 & 0.98 \\
\hline $\mathrm{V}_{3}$ & 3.96 & 1.29 \\
\hline $\mathrm{V}_{1}$ & 3.94 & 0.98 \\
\hline $\mathrm{V}_{12}$ & 3.93 & 0.96 \\
\hline $\mathrm{V}_{4}$ & 3.73 & 1.09 \\
\hline $\mathrm{V}_{11}$ & 3.63 & 1.05 \\
\hline \multicolumn{3}{|l|}{ Significant } \\
\hline $\mathrm{V}_{2}$ & 3.43 & 1.37 \\
\hline $\mathrm{V}_{7}$ & 3.23 & 1.09 \\
\hline $\mathrm{V}_{5}$ & 3.21 & 0.89 \\
\hline $\mathrm{V}_{10}$ & 3.18 & 0.99 \\
\hline $\mathrm{V}_{8}$ & 3.17 & 1.41 \\
\hline \multicolumn{3}{|l|}{ Insignificant } \\
\hline $\mathrm{V}_{6}$ & 2.76 & 1.13 \\
\hline
\end{tabular}


After analyzing weighted mean score five most significant variables $\left(\mathrm{V}_{9}, \mathrm{~V}_{3}, \mathrm{~V}_{1}, \mathrm{~V}_{12}, \mathrm{~V}_{4}\right.$ and $\left.\mathrm{V}_{11}\right)$, six significant variables $\left(\mathrm{V}_{2}, \mathrm{~V}_{7}, \mathrm{~V}_{5}, \mathrm{~V}_{10}\right.$ and $\left.\mathrm{V}_{8}\right)$ and one insignificant variable $\left(\mathrm{V}_{6}\right)$ of corporate governance have been found in ethical investment of the bank. After using Varimax rotation method, two factors containing variables of corporate governance have been found whose explain $58 \%$ of total variance among the variables. Among all the variables of corporate governance, internal audit system of the bank plays a crucial rule in ethical investment practices across the investment function of the bank. $37.45 \%$ of the total respondents strongly agreed that if the internal audit system of the bank is well designed comprised with qualified staffs and accuracy report the investment of the bank will be ethical. Because the auditors of the bank critically examine the investment practices of the bank that is in which sectors the bank invests. Auditors periodically reports to the board about the investment performance and board takes investment strategy on the basis of auditors' report.

This finding is also supported from the finding of board own structure and practices variable. $46.3 \%$ of the respondents strongly agreed that if the bank maintains a structured committee like audit committee, risk committee, compliance committee, ethics committee etc. with well leadership then bank can ensure ethical investment practices in overall investment practices. Chairman role plays a vital effect in compromising the board structure and also in decision making process. Board's overall responsibilities in strategic decision making and its implementation influence the good governance practices (36\% of respondents strongly agreed on it). Board's members are responsible for ensuring good governance practices by performing their duties with loyalty and thereby increasing awareness corporate culture and values regarding ethical investment (Renneboog et al., 2008; Gu, 2018).

With the interaction with supervisors board will take the proper policies regarding the ethical values in investment decision. Supervisors periodically reviews the performance of policies practiced in the investment functions to recommend the strategic issues regarding ethical investment. Supervisors should focus particular attention on the oversight of the risk management, compliance, investment practices, ethical issues and internal audit functions with the interaction between board and representatives of these functions (35.4\% of respondents agreed on this issues). Senior management carries out the planned policies approved by the board on the banking practices. Senior management is responsible for ensuring good communication and compliance system across the bank to run the investment activities ethically. 30.9\% of the total respondents argued that if the senior management delegates duties to staff and performs personal conduct on staffs' duties the ethical investment culture can be ensured. Compliance (25.8\% of respondents agreed on it) and communication system (32.6\% respondents agreed on it) from top to bottom line of the bank ensures the ethical behaviour of the personnel on their investment activities. Compensation of managerial personnel influences the behaviour of investing the funds ethically because problems in incentive plan creates agency problem which negatively affects the ethical behaviour in investment (Tirole, 2001). Independent and internal control infrastructure of risk management will critically evaluates the risk materials of ethical investment funds of the banks to ensure whether the ethical investment is performing as board's strategic plans and board will be accountable to disclose the reports about the performance of the ethical investment funds to its stakeholders.

\section{Conclusion}

Corporate governance plays a dynamic role in the business world. Good governance in firm ensures the performance as well as competitiveness of the firm. Agency problem which hinders the well growth of firm is reduced by the good governance. It is more important for the bank because bank deals with other funds on the basis of trust. We constructed twelve corporate governance variables by using total of 38 sub-indices affecting the governance of bank. Results indicate that transparency of CEO, CRO and board's members and their loyal duties establish good governance and therefore ensure corporate culture and values which affect risk management of the bank. Senior management and supervisors roles on board are needed to be efficient in risk management because they are ultimate responsible for taking strategy in business units. Performance based incentives plan and efficient compliance system from top to bottom level of the bank creates transparency and accountability in the assigned functions which reduce operational risk of the bank. Timely disclosures of risk issues with the interaction of audit committee report reduce the market risk of the bank. To be more efficient in risk management bank should use updated techniques for assessing and need well knowledgeable staffs in audit and risk committee. From the side of ethical investment, it is found that auditors' accountability and reports on ongoing processes of bank promote the ethical investment behavior of the bank. Board composition like independent directors and well designed committee with skilled and knowledgeable personnel creates the corporate culture and values on ethical issues across the bank. As like as board, supervisors are also responsible for ensuring ethical investment practices in the bank. It is also found that compensation of managerial personnel influences the behavior of investing the bank's funds. 


\section{References}

Adams, R. B., \& Mehran, H. (2003). Is corporate governance different for bank holding companies?.

Aebi, V., Sabato, G., \& Schmid, M. (2012). Risk management, corporate governance, and bank performance in the financial crisis. Journal of Banking \& Finance, 36(12), 3213-3226. https://doi.org/10.1016/j.jbankfin.2011.10.020

Ahmed, U., Khalid, N., Ammar, A., \& Shah, M. H. (2017). Assessing moderation of employee engagement on the relationship between work discretion, job clarity and business performance in the banking sector of Pakistan. Asian Economic and Financial Review, $1197-121$. https://doi.org/10.18488/journal.aefr.2017.712.1197.1210

Akram, A., Omair, M., Ameen, H., Babar, Z. K., \& Jaskani, J. H. (2014). Variables affecting Corporate Governance in the Profitability of Banks in Pakistan. International Journal of Accounting and Financial Reporting, 4(2), 66. https://doi.org/10.5296/ijafr.v4i2.6080

Amba, S. M. (2014). Corporate governance and firms' financial performance. Journal of Academic and Business Ethics, 8, 1-11.

Anas, E. L. M. E. L. K. I., \& Mounira, B. A. (2009). Ethical investment and the social responsibilities of the Islamic banks. International Business Research, 2(2), 123. https://doi.org/10.5539/ibr.v2n2p123

Bansal, P., \& Roth, K. (2000). Why companies go green: A model of ecological responsiveness. Academy of Management Journal, 43(4), 717-736. https://doi.org/10.5465/1556363

Beasley, M. S. (1996). An empirical analysis of the relation between the board of director composition and financial statement fraud. Accounting Review, 443-465.

Black, B. S., Jang, H., \& Kim, W. (2006). Does corporate governance predict firms' market values? Evidence from Korea. Journal of Law, Economics, and Organization, 22(2), 366-413. https://doi.org/10.1093/jleo/ewj018

Brown, S., \& Skully, M. (2006). Ethical investments and performance of Islamic banks. Journal of Islamic Economics, Banking and Finance, 5(1).

Calomiris, C. W., \& Carlson, M. (2016). Corporate governance and risk management at unprotected banks: National banks in the 1890s. Journal of Financial Economics, 119(3), 512-532. https://doi.org/10.1016/j.jfineco.2016.01.025

Durnev, A., \& Kim, E. (2005). To steal or not to steal: Firm attributes, legal environment, and valuation. The Journal of Finance, 60(3), 1461-1493. https://doi.org/10.1111/j.1540-6261.2005.00767.x

Faleye, O., \& Krishnan, K. (2010, August). Risky Lending: Does Bank Corporate Governance Matter?. In 23rd Australasian Finance and Banking Conference. https://doi.org/10.2139/ssrn.1661837

Friedman, A. L., \& Miles, S. (2001). Socially responsible investment and corporate social and environmental reporting in the UK: an exploratory study. The British Accounting Review, 33(4), 523-548. https://doi.org/10.1006/bare.2001.0172

Ge, J., Wang, X., Wu, P., Huang, T., \& Jiang, H. (2018). Establishing Shipping Service Complex Standard Framework: Experience from Shanghai. International Journal of Management and Sustainability, 7(4), $215-224$. https://doi.org/10.18488/journal.11.2018.74.215.224

Gérard, T., \& Oumbé, T. (2018). Trade Policy and Democracy for Development in Central African Countries. Journal of Empirical Studies, 5(1), 55-66. https://doi.org/10.18488/journal.66.2018.51.55.66

Ghanney, R. A. (2018). How parental education and literacy skill levels affect the education of their wards: The case of two schools in the Effutu municipality of Ghana. International Journal of Education and Practice, 6(3), 107-119. https://doi.org/10.18488/journal.61.2018.63.107.119

Goral, R., \& Akgoz, E. (2017). Tourism Price Competition Index for National Destinations. Journal of Tourism Management Research, 4(1), 17-29. https://doi.org/10.18488/journal.31.2017.41.17.29

$\mathrm{Gu}$, Z. (2018). On Overseas Chinese Teaching from the Perspective of Intercultural Communication. International Journal of Education, Training and Learning, 2(1), 13-15. https://doi.org/10.33094/6.2017.2018.21.13.15

Haldar, A. (2012). Corporate Governance Index for Listed Indian Companies. Indian Institute of Technology SJMSOM Working Paper, December. 
Hofmann, E., Meier-Pesti, K., \& Kirchler, E. (2007). The decision process for ethical investment. Journal of Financial Services Marketing, 12(1), 4-16. https://doi.org/10.1057/palgrave.fsm.4760057

Hussein, K. (2004). Ethical investment: empirical evidence from FTSE Islamic index. Islamic Economic Studies, 12(1), 21-40.

Islam, F., Muhammad Adnan Hye, Q., \& Shahbaz, M. (2012). Import-economic growth nexus: ARDL approach to cointegration. Journal of Chinese Economic and Foreign Trade Studies, 5(3), 194-214. https://doi.org/10.1108/17544401211263964

Junaid, I. (2018). Assessing Competencies of Tourism Students through Poster Presentation: Evidence from Indonesia. Journal of Tourism Management Research, 5(1), 1-13. https://doi.org/10.18488/journal.31.2018.51.1.13

Kaine, A. I. N., Iku, J. E., \& Ebigwai, S. J. (2015). Analysis of Determinants of Demand and Supply of Maize in Aniocha North Local Government Area, Delta State, Nigeria. International Journal of Sustainable Agricultural Research, 2(1), 12-21. https://doi.org/10.18488/journal.70/2015.2.1/70.1.12.21

Louche, C. (2004). Ethical Investment: Processes and mechanisms of institutionalisation in the Netherlands 1990-2002. Doctoral dissertation, Bestuurskunde, Public Administration.

Macey, J. R., \& O'hara, M. (2003). The corporate governance of banks. Economic Policy Review, 9(1).

Michelson, G., Wailes, N., Van Der Laan, S., \& Frost, G. (2004). Ethical investment processes and outcomes. Journal of Business Ethics, 52(1), 1-10. https://doi.org/10.1023/B:BUSI.0000033103.12560.be

Nworji, I. D., Adebayo, O., \& David, A. O. (2011). Corporate governance and bank failure in Nigeria: Issues, challenges and opportunities. Research Journal of Finance and Accounting, 2(2), 27-44.

Pirson, M., \& Turnbull, S. (2011). Corporate governance, risk management, and the financial crisis: An information processing view. Corporate Governance: An International Review, 19(5), 459-470. https://doi.org/10.1111/j.1467-8683.2011.00860.x

Renneboog, L., Ter Horst, J., \& Zhang, C. (2008). Socially responsible investments: Institutional aspects, performance, and investor behavior. Journal of Banking \& Finance, 32(9), 1723-1742. https://doi.org/10.1016/j.jbankfin.2007.12.039

Richardson, B. J. (2009). Keeping ethical investment ethical: Regulatory issues for investing for sustainability. Journal of Business Ethics, 87(4), 555-572. https://doi.org/10.1007/s10551-008-9958-y

Santomero, A. M. (1997). Commercial bank risk management: an analysis of the process. Journal of Financial Services Research, 12(2-3), 83-115. https://doi.org/10.1023/A:1007971801810

Schäfer, H. (2004). Ethical investment of German non-profit organizations-conceptual outline and empirical results. Business Ethics: A European Review, 13(4), 269-287. https://doi.org/10.1111/j.1467-8608.2004.00370.x

Suryanto, T., Haseeb, M., \& Hartani, N. H. (2018). The Correlates of Developing Green Supply Chain Management Practices: Firms Level Analysis in Malaysia. International Journal of Supply Chain Management, 7(5), 316.

Tandelilin, E., Kaaro, H., \& Mahadwartha, P. A. (2007). Corporate governance, risk management and bank performance: Does type of ownership matter. EADN Individual Research Grant Project, 34, 115-118.

Tippet, J. (2001). Performance of Australia's ethical funds. Australian Economic Review, 34(2), 170-178.

Treynor, J., \& Mazuy, K. (1966). Can mutual funds outguess the market. Harvard Business Review, 44(4), 131-136.

Tsorhe, J. S., Aboagye, A. Q., \& Kyereboah-Coleman, A. (2011). Corporate governance and bank risk management in Ghana.University of Ghana Business School.

Van Greuning, H., \& Brajovic-Bratanovic, S. (2003). Analyzing and managing banking risk: a framework for assessing corporate governance and financial risk management. Documents \& Reports, The World Bank. https://doi.org/10.1596/0-8213-5418-3

Willesson, M. (2015). Risk and Efficiency in European Banking-Does Corporate Governance Matter?. Bank Risk, Governance and Regulation (pp. 163-181). Palgrave Macmillan UK. https://doi.org/10.1057/9781137530943_6

Yermack, D. (1996). Higher market valuation of companies with a small board of directors. Journal of Financial Economics, 40(2), 185-211. https://doi.org/10.1016/0304-405X(95)00844-5 


\section{Appendix}

Appendix 1. Corporate Governance and Risk Management

\begin{tabular}{lll}
\hline KMO and Bartlett's Test & & \\
\hline Kaiser-Meyer-Olkin Measure of Sampling Adequacy. & .876 \\
\hline Bartlett's Test of Sphericity & Approx. Chi-Square & 879.923 \\
\cline { 2 - 3 } & df & 78 \\
\cline { 2 - 3 } & Sig. & .000
\end{tabular}

Appendix 2. Corporate Governance and Ethical Investment

\begin{tabular}{lll}
\hline KMO and Bartlett's Test & & \\
\hline Kaiser-Meyer-Olkin Measure of Sampling Adequacy. & .657 \\
\hline Bartlett's Test of Sphericity & Approx. Chi-Square & 344.495 \\
\cline { 2 - 3 } & $\mathrm{df}$ & 66 \\
\cline { 2 - 3 } & Sig. & .000 \\
\hline
\end{tabular}

